Article

\title{
Addressing Energy Poverty through Transitioning to a Carbon-Free Environment
}

\author{
Sofia-Despoina Papadopoulou, Niki Kalaitzoglou, Maria Psarra, Sideri Lefkeli, \\ Evangelia Karasmanaki * and Georgios Tsantopoulos
}

Department of Forestry and Management of the Environment and Natural Resources, Democritus University of Thrace, 68200 Orestiada, Greece; sofiapapadopoulou93@gmail.com (S.-D.P.); kalaitzoglouniki@gmail.com (N.K.); maria.psarra72@gmail.com (M.P.); roylaleu@hotmail.gr (S.L.); tsantopo@fmenr.duth.gr (G.T.)

* Correspondence: evagkara2@fmenr.duth.gr; Tel.: +306-983-605-600

Received: 14 April 2019; Accepted: 6 May 2019; Published: 8 May 2019

check for updates

\begin{abstract}
The excessive consumption of fossil fuels not only leads to resource depletion, but also involves negative environmental effects on both public health and the climate. However, Greece's renewable energy (RE) capacity is considerable and could meet a great part of the country's energy needs while helping to tackle the ecological problem our planet faces. At the same time, the deployment of renewable energy sources (RES) can facilitate the creation of new jobs and enable households to become energy independent, while addressing energy poverty. The present study investigates the views and attitudes of citizens of the Thessaloniki conurbation towards RES. To collect the data, structured questionnaires were used, which were completed through personal interviews. Moreover, random sampling was performed to select the sample, and in total 420 citizens participated in the survey. Results showed that the respondents supported the replacement of lignite plants with renewable energy sources since they perceived that they constitute a necessary solution providing opportunities for economic growth and improvement to their quality of life. Finally, the vast majority expressed increased interest in future investment in photovoltaic systems, which in their opinion could contribute to improving air quality and increasing the energy independence not only of Greece but also of households.
\end{abstract}

Keywords: Renewable energy sources; energy poverty; energy transition; citizen attitudes; Thessaloniki

\section{Introduction}

Economic growth is dependent on energy which supports economic activity, enhances productivity and meets basic human needs. The energy sector lies at the core of challenges and European countries' attention has turned to renewable energy sources due to the uncertainty of fossil reserves and their negative environmental effects. To alleviate environmental problems, the member states of the European Union (EU) are required to take immediate action for the development of new energy production technologies, and to that end the EU has established a legislative framework which provides for the promotion and use of renewable energy sources [1]. In particular, the Directive 2001/77/EC was introduced, which provided that $12 \%$ of the energy produced within the EU should be generated from renewable sources [2]. A few years later, the European Commission proposed the Directive 2009/28/EC, encouraging the development of renewable energy technologies [3].

In the context of the European Energy Policy, the National Renewable Energy Action Plan was established in Greece for energy saving. According to the plan, renewable energy sources must be promoted for electricity generation and Greece is bound to meet certain environmental commitments 
regarding the set targets of 2020. To achieve the set targets, the suggested RES technologies involved both onshore and offshore wind energy, photovoltaic technology, as well as geothermal energy [4].

To plan effective policies for the sustainable development of natural resources, it is significant to fully understand and consider human environmental behavior [5]. In other words, it appears that knowing the attitudes and behavior of citizens is particularly important to energy policy design. Indicatively, the Swedish Energy Policy has attributed great importance to environmental behavior and was greatly affected by the Swedish citizens' attitudes towards energy production and management [6]. In addition, it was indicated that the understanding of citizens' attitudes and behavior in terms of sustainable energy management has been rapidly increasing in the past years, mainly due to the need for better communication between decision-makers and the public being highlighted [7].

In our age, the estimations of energy technology are extensive in environmental and economic terms and at the same time citizens' concerns about environmental issues and energy saving have increased. For example, research has identified that in the years 2001-2002 the inhabitants of the Greek islands were supportive of the existing wind parks in contrast to the inhabitants of the mainland who had a negative attitude [1]. More specifically, the inhabitants of the mainland expressed either divided opinions on or negative attitudes to wind energy applications, highlighting the need for providing residents with additional information on wind power [8]. As for photovoltaic system application, the research findings of Hondo and Baba [9] are of great interest since this research team discovered that 200 household heads in Lida were interested in electricity saving and estimated the costs and benefits from photovoltaic application, while as community members communicated with each other on the system's usefulness and developed a more positive behavior concerning the management of the natural environment [9].

In periods of recession and financial credit, increased development levels cannot ensure the continuous access to efficient forms of energy and consequently the phenomenon of energy poverty emerges [10]. According to the Community Directive 2009/72/EC, in Europe energy poverty is reaching worrying proportions and requires an immediate response [11]. In Greece, energy poverty stems from the economic crisis and was first noticed in the initial years of the crisis, while the scale of energy poverty compelled the Greek state to form an appropriate policy to address this issue.

To put this differently, energy poverty emerges when lower-income households have difficulty covering energy costs for electricity and heating purposes. Installations of renewable energy, and especially photovoltaic systems, provide households with the opportunity to become energy independent and combat the problem of energy poverty. A necessary condition for this to happen is that citizens invest in renewables. However, no study has examined the investment willingness and attitudes towards renewable energy of citizens residing in large cities such as Thessaloniki. Hence, the main aim of the present study is to examine the views of the citizens of the Thessaloniki conurbation on a set of issues concerning energy production from different sources, investments in renewable energy and predominantly in photovoltaic systems, which can contribute significantly to the reduction of energy poverty. The study findings can make an important contribution because they can be used as an effective tool by policymakers to make decisions on policies and adapt their decisions to the new data. To be more specific, having insights into citizens' mindset can help policymakers formulate policies and introduce measures which correspond to citizens' expectations and needs. In the long run, a favorable climate for citizen investment in RES can be fostered, which in turn will address energy poverty.

\section{Theoretical Background}

Energy, energy use and carbon emissions reduction are widely recognized as the most important environmental issues of our time, while they are also crucial to economic and social development, as well as the improvement of life quality $[12,13]$. To achieve a substantial reduction in greenhouse gas emissions, increasing the share of renewable energy sources in the total energy production is becoming the most important aspect of strategies in many countries [14]. 
Renewable energy sources play a key role in environmental protection since their exploitation does not harm the environment due to the lack of pollutants or gases which increase the risk of climate change. Simultaneously, the use of RES for electricity production can contribute greatly not only to reducing the dependence on the expensive imported oil but also to reinforcing energy security $[15,16]$. Apart from the reduction in environmental pollution and the enhancement of energy saving, the creation of new jobs consists another notable advantage of renewable energy deployment [17]. Yet, investments in RES often involve external costs and benefits which should be taken into account to achieve socially optimal investments [14].

The adoption and promotion of renewable energy technologies have become more and more important to environmental and economic sustainability, as global concerns about climate change and dependence on imported fossil fuels are increasing $[18,19]$. Specifically, solar energy is not only abundant, but also consists one of the fastest growing renewable sources, since it does not contribute to carbon emissions and hence is not harmful to the environment [20].

At the European Union level, the pursued energy policy has attempted to develop coherent strategies to set objectives common to all countries which include pollution reduction and growth in renewable energy use. In the context of the Europe 2020 strategy, the countries of the EU are committed to maintain the 20/20/20 targets in terms of climate/energy. In essence, this means that there should be $20 \%$ reduction in greenhouse gas emissions compared to the levels recorded in $1990,20 \%$ increase in the share of renewable sources of energy in total energy production and $20 \%$ increase in energy efficiency. Notably, these targets are inseparable from the targets which are set for education, employment, innovation and fight against poverty and at the same time they are of vital importance for the overall success [21]. The reduction in greenhouse gas emissions by $40 \%$ below the 1990 levels as well as the other targets relating to RES and energy efficiency in EU are included in the "Energy Roadmap 2050" [22]. Hence, the competitiveness and security of energy supply can be secured, while the transition to a low-carbon economy and energy system decentralization can be supported through energy technology innovation [23].

Today, the European Union constitutes the biggest economy which is legally bound to attain $27 \%$ energy consumption from RES by 2030. To achieve this objective, electricity production from RES must reach 1600-1700 TWh by 2030, which is double than the corresponding rate in 2014 [24]. According to the latest reports, the European Union has made great progress since 2005 and is well on course to meet the 2020 renewable energy targets [25]. However, research has indicated that the Directive 2009/28/EC on EU action, which is responsible for the application of the general policy on the RES targets by member states, does not provide the structure or the content needed by member states to apply the RES policy and achieve the set targets [3].

In times of austerity and increasing energy poverty, the improvement of energy autarky through RES is characterized as an economic savior. At a national level, renewable energy sources can constitute a long-term solution to international dependence on fuel imports, pan-European energy security and a way to eliminate failed economies due to financial abuse [26]. Ensuring access to imported energy resources in advantageous and competitive terms is the primary target for the international relations of the energy dependent countries. International relations are of great significance to the solution of the energy issue especially in countries lacking energy autonomy such as Greece [27].

The use of electricity is a prerequisite for modern living, however, energy production entails high monetary and environmental costs. For this reason, energy saving measures are required and energy production must be covered as much as possible by RES [15], rendering the harmonization and adjustment of the Greek energy market and institutional framework to the current international trends, perceptions and requirements [27]. It is reasonable therefore that the focus is on specific sectors. These involve the liberalization of the gas and electricity market, increase in the production of electricity from renewable energy sources, reduction in energy generated by conventional technologies, improvement of energy efficiency, energy saving and environmental protection with a focus on the domestic sector. Meanwhile, the Greek energy market is presently experiencing rapid and radical changes [28]. 
At this point it is interesting to provide a context of the energy situation in Greece. The photovoltaic system in Greece began in 2006 and was updated in 2011, providing potential financial stability and consisting an alternative to oil and lignite, while the latter is today still dominant in the energy sector. The program promoted new opportunities for both small-scale photovoltaic applications for households and large-scale photovoltaic parks producing enough energy for international exports. However, in such cases there is often opposition to be faced, while the energy program's success or failure can be affected by the understanding of local social relations and historical consciousness, but also by government policy [26]. In Greece, since 2009 a type of unregulated investor policy has seemed to prevail, which is characterized by a high number of applications for constructing renewable energy projects. Such projects are often implemented without strategic planning and involve large-scale construction projects in small island regions while environmental and cultural limitations specified in the relevant legislation are being violated. Meanwhile, local communities are not informed and existing industries, rural and domestic activities, as well as land qualities are neglected giving thus rise to common sense [29]. Considering the above, Greece must evaluate two more elements. First, local and regional authorities now participate in environmental policymaking and implementation without however possessing the necessary fiscal and administrative capacities while signs of customer relations and corruption are observed [30]. Second and most important, the EU involvement through troika [31] has been dramatically affecting the conditions of environmental development in Greece since the year 2010 [32] through a set of legislative changes including investment facilitation and national economy boosting [33]. It is clear that the success of national policy is inevitably directly related to international relations [34]. Possibly, the most important issue that Greece faces in terms of policies, is the constant political regression which causes alterations in the institutional and economic frameworks relating to RES development. The resulting uncertainty consists an inhibiting factor for investors and at the same time frustration occurs among social groups residing in areas where renewable energy projects are to be implemented [15,35].

In terms of the total electricity production in Greece, the official data of the Ministry of Environment and Energy are of great interest and show that there is a constant increase in electricity production. Specifically, an increasing trend in electricity production is observed and the greatest share of energy production is lignite-based, while natural gas has been introduced to the energy mix and a gradual increase in energy from renewables is noticed [36]. Interestingly, the expectations of natural gas development seem to play a preventive role in decision-making regarding the long-term development of solar photovoltaic energy [37]. Meanwhile, the most important impacts of the operation of fossil fuel power plants involve the harmful effects on human health and the increased concentration of carbon dioxide in the air [38]. Acknowledging these effects, Law No 3851/2010 provided mandatory national targets for the RES share in overall energy consumption [39], highlighting the cooperation between industry and government $[18,40]$ which should also cooperate with households [41]. This way the benefits of microgeneration as part of a wider shift towards reducing energy demand and consumer behavior change can be secured. That is particularly important especially because households often ignore their important contribution to these targets [42]. Moreover, suppliers should endeavor to better understand the perceptions of customers, so they can develop technology products which are attractive to the current household owners [34].

In this context, many private and public investors have repeatedly made efforts to install new RES-based plants inducing often serious local opposition [40]. For this reason, the different character of local preferences for RES should be taken into consideration [4]. The dynamic of public commitment in the technological development of RES [43] is able to address public attitudes which constitute obstacles or barriers, by shaping citizens' perceptions in this direction $[6,44,45]$. This can be achieved by involving citizens in the initial planning and implementation stages [46], and especially citizens residing close to installation sites [47]. Additionally, it would be useful to provide citizens with information on the major advantages of wind and solar system use, which are not only effective, economical, efficient and environmentally friendly sources, but also ones that generate lower greenhouse gas emissions. 
However, it is possible that the manufacturing procedures of the materials of these systems cause harmful emissions as it is the case with other products. Consequently, the possibility of negative effects must be monitored within a comparative life-cycle framework [38] in rural rather than urban areas [48] to achieve a sustainable future $[16,44,46,47]$. It is noteworthy that renewable energy sources cannot bring about significant changes, but people must change habits so that society can attain a "green future" [15]. Public opinion is generally considered particularly inconsistent, while perceptions are referred to as social and personal [49] and attitudes differ substantially from one project to another, among regions but also within the same region and can change over time. In reality, public opinion depends on various factors such as ignorance, misinformation regarding the advantages of a specific technology, local environmental conditions, national energy policies, residents' experience in such projects, renewable energy technology costs $[40,44,45]$. Consumer behavior is complicated and rarely follows traditional economic decision-making theories. When people buy goods, they often believe that they take smart decisions and act "rationally". Yet, in their everyday life people deviate from the model of "rational behavior" [50], according to which a person estimates the cost and advantages of alternative solutions objectively before making the final decision. Even consumers with strong material motives possessing adequate knowledge and motives to act in sustainable ways are likely to change their behavior towards a more desirable direction [50]. However, high knowledge of the basic principles and contribution of RES is observed, while great awareness levels about environmental problems are recorded. More specifically, there is substantial support for RES installations [34,51], especially for existing RES projects (particularly photovoltaic systems, wind parks and hydropower applications) without rejecting new installations which does not resonate with the NIMBY phenomenon $[1,40,46,49,52]$. Awareness about the issue of climate change and other environmental problems as well as high concern levels about the environment regarding the future seems to be a factor validating renewable energy $[6,19,51]$. Simultaneously, most expressed concerns are based on the impact of photovoltaics on land-use and of hydropower stations on flora and fauna and not so much on the noise produced by wind turbines [18,40]. For example, in regions of Greece with high wind capacity and investment interest the public has a supportive attitude towards wind energy applications including both existing and new turbines, whereas in continental Greece public opinion is divided [8]. Nevertheless, the same study revealed that a minority consisting mainly of farmers was acutely opposite to wind energy applications ignoring the economic benefits [8].

Moreover, a possible existence of the snowball effect was noticed regarding the acceptance and support for RES if some minorities changed their lifestyle [2], wishing that the responsibility of climate change action is transferred to governments. However, the cooperation ability of citizens (collective action) on a moral and voluntary basis to achieve behavioral change was deemed limited. This has consequences for policies on energy and resources usage. In this context, it may be useful that policymakers first establish policies which are considered most appropriate for the public and second take initiatives through information and communication campaigns examining citizens' concerns about the usefulness of government approaches [5].

On the other side, citizens' limited sense of personal responsibility suggests that energy efficiency and RES installation on individual level is pointless and lacks significant motives. Shares of citizens have expressed many arguments regarding the safeguarding of future generations and lifestyle changes to justify RES installations. In addition, there are positive correlations between energy efficiency and lifestyle changes, but the latter are not fully negotiable $[1,5,53]$. A recent study has identified the willingness of citizen majority to pay more for electricity generated by RES, either in the form of payment for public projects or domestic system installation which provide long-term economic profit $[6,15]$. What is more, another study has indicated that certain groups of citizens were more willing to pay for renewables than others. These involved high earners, owners of large houses, individuals with high knowledge and awareness levels about energy and climate change, as well as people facing electricity shortage [54]. Apart from citizen groups, tourists also exhibited positive 
attitudes to RES since they stated their preference for hotels which have invested in energy saving measures and RES even if they were required to pay higher prices [55].

Yet, the cost still constitutes a notable barrier to the adoption of pro-environmental behavior in the form of adopting renewable energy systems, while the availability and price of technologies are constantly changing. In relation to solar energy, it has been indicated that not owning a roof or a plot of land consists a significant hindrance to photovoltaic (PV) installation $[35,56]$ and, at the same time, plans to move to another house and lack of house ownership affect consumer perception [57]. On the other side, obstacles to wind energy implementation often occur when the local public resists installations on grounds of the visual impact of such projects on the landscape [58-60]. It therefore becomes clear that RES policymaking should ensure that the long-term benefits of RES investment will offset the cost of participating in positive environmental behavior through "green subsidies" [61].

From the citizens' viewpoint, an overall support for RES development was observed, which was closely related to the dissemination of solar water heaters [53]. This support can be accounted for by the fact that a significant part of the household's warm water demand can be covered by solar water heating systems which cover even $70 \%$ while involving a short depreciation time [16]. Simultaneously, it would be beneficial to inform citizens about topics on photovoltaic system installation including cost reduction due to system integration into building parts such as windows and tents [62]. Moreover, it has been found that households which are familiar with photovoltaic systems tend to enhance their daily environmental behavior [9]. However, the same does not apply to wind energy since citizens are prevented from adopting it due to turbines' high cost and size granting thus exclusivity to multinational companies [31,52].

The understanding of citizens' attitudes and the stages undergone before deciding to adopt RES is not only varied but can also have great influence. Hence, the understanding can enable those in governments to design more effectively strategic policies which aim at enhancing citizen acceptance of RES while acknowledging citizens' expectations which mainly involve financial incentives. Moreover, they will be able to reinforce the appropriate supportive and educational means. Second, greater control of marketing strategy should be exercised to make this technology more attractive and affordable even for households suffering from or threatened by energy poverty, enabling investments in RES-based electricity production.

\section{Materials and Methods}

The present study was performed in the city of Thessaloniki. To achieve the research objectives, it was deemed necessary to use structured questionnaire and personal interviews because these are considered effective when it is attempted to capture the views of a large number of respondents [63]. In particular, the questionnaire allows the participation of a great number of participants facilitating the identification of possible differentiated or opposite tendencies regarding electricity production from lignite and RES, which would not have possibly been discovered by a different quantitative method. Hence, this method contributes more effectively to a more thorough understanding of the topics investigated by this study.

To design the questionnaire, the relevant literature on citizen views and attitudes towards household photovoltaic system installation was taken into account $[9,15,16,34,40,42,46]$. To analyze the collected data, descriptive statistics, the non-parametric Friedman test and factor analysis were the chosen methods. The Friedman test is a statistical method that is applied to compare the values of three or more groups of variables which are correlated. Also, the distribution of the Friedman test is $\chi^{2}$ distribution with degrees of freedom ( $\left.d f\right) d f=k-1$, where $k$ stands for the number of teams or samples. In addition, the test analyses the values of variables for each subject separately and estimates the mean ranks of classification values for each variable [64,65]. On the other side, factor analysis is a statistical method which investigates whether there are common factors within a group of variables. More specifically, principal component analysis was performed here, which is on the basis of the spectral analysis of the variance (or correlation) matrix [66,67]. Moreover, the criterion employed for 
the significance of the principal components was the one suggested by Guttman and Kaiser, which states that the limit for acquiring the required number of principal components is determined by the eigenvalues which are equivalent to or greater than one. Then, we carried out a matrix rotation of the principal components using the Kaiser's varimax rotation method to obtain more coherent results [68].

Regarding the sampling method, we selected the simple random sampling because it is not only simple but also requires less knowledge about the population than any other sampling method. In total, 420 residents in the Thessaloniki conurbation completed the questionnaire and the data collection was implemented in the period between June-July 2018.

\section{Results}

Regarding the socio-demographic characteristics of the participants, female respondents (53.3\%) outnumbered their male counterparts, while more than half (56\%) were aged between 31 and 50 years and considerably fewer were aged between 51 and 60 years. In terms of educational level, it was indicated that overall the participants were highly educated, since over half of the surveyed citizens were university or technical institution graduates, whereas only one in five respondents had attended merely high school. Moreover, in terms of occupation, most participants were employed in the private sector $(30.7 \%)$, whereas $20.5 \%$ were public servants and $12.6 \%$ were unemployed. In addition, $11.7 \%$ were higher education students, while the percentages of freelancers, farmers and people involved in housework were particularly low. Finally, regarding the gross annual household income, $21.2 \%$ of respondents earned from 10.001 to $20.000 €$, while $19 \%$ received from 5001 to $10,000 €$ and $17.9 \%$ less than $5000 €$. At the same time, $15.5 \%$ of participants received from 20,001 to $30,000 €$ and only $6 \%$ more than $30,000 €$. It is also noteworthy that a substantial proportion $(20.5 \%)$ of the surveyed citizens did not wish to report their income.

Citizens were first asked whether they agreed that renewable energy sources offer opportunities for economic growth. As presented in Table 1, most participants, by $84.8 \%$, agreed with this statement, whereas only $5.5 \%$ disagreed. Moreover, as it can be seen in Table 2 more than half respondents $(53.5 \%)$ considered that Greece has not invested in renewable energy sources, while only $11.4 \%$ perceived that the Greek state has invested in RES.

Table 1. Frequency and percentages regarding the degree of agreement with the view that renewable energy sources offer opportunities for economic growth.

\begin{tabular}{ccc}
\hline & Frequency & Percentage (\%) \\
\hline Do not know & 12 & 2.9 \\
Totally disagree & 10 & 2.4 \\
Disagree & 13 & 3.1 \\
Neither agree nor disagree & 29 & 6.9 \\
Agree & 191 & 45.5 \\
Totally agree & 165 & 39.3 \\
Total & 420 & 100.0 \\
\hline
\end{tabular}

Table 2. Frequency and percentages concerning participants level of agreement with the view that the Greek state has invested in renewable energy sources.

\begin{tabular}{ccc}
\hline & Frequency & Percentage (\%) \\
\hline Do not know & 65 & 15.5 \\
Totally disagree & 61 & 14.5 \\
Disagree & 164 & 39.0 \\
Neither agree or disagree & 82 & 19.5 \\
Agree & 27 & 6.4 \\
Totally agree & 21 & 5.0 \\
Total & 420 & 100.0 \\
\hline
\end{tabular}


Next, the citizens' degree of agreement with the gradual reduction in lignite-based power generation and transition to environmentally friendlier energy types was investigated. As Table 3 shows, the vast majority (90.7\%) supported this change and only $3.1 \%$ of respondents disagreed, while $6.2 \%$ neither agreed nor disagreed. Afterwards, citizens' view on the construction of new lignite plants in regions where lignite reserves are located was examined. Remarkably, most citizens were opposed to constructing new lignite plants (58.8\%), while those supporting the construction were $16.9 \%$ and those taking a neutral position were $24.3 \%$ (Table 4 ).

Table 3. Frequency and percentages concerning respondents' view on the gradual reduction in lignite-based electricity production and transition to environmentally friendly energy types.

\begin{tabular}{ccc}
\hline & Frequency & Percentage (\%) \\
\hline Totally disagree & 6 & 1.4 \\
Disagree & 7 & 1.7 \\
Neither agree nor disagree & 26 & 6.2 \\
Agree & 158 & 37.6 \\
Totally agree & 223 & 53.1 \\
Total & 420 & 100.0 \\
\hline
\end{tabular}

Table 4. Frequency and percentages relating to citizens' degree of agreement with the construction of new lignite plants in areas with lignite resources.

\begin{tabular}{ccc}
\hline & Frequency & Percentage (\%) \\
\hline Totally disagree & 103 & 24.5 \\
Disagree & 144 & 34.3 \\
Neither agree nor disagree & 102 & 24.3 \\
Agree & 61 & 14.5 \\
Totally agree & 10 & 2.4 \\
Total & 420 & 100.0 \\
\hline
\end{tabular}

Afterwards, the participants evaluated the impacts which would arise if the existing lignite plants were replaced with installations of renewable energy sources. To scrutinize the data, responses were ranked using the non-parametric Friedman test (Table 5). According to the test results, the surveyed citizens of the Thessaloniki conurbation regarded the improvement of life quality in the nearby areas as the most important advantage if renewable energy sources replaced exiting lignite plants (mean rank 5.93). This was followed by the protection of the regional flora and fauna (mean ranks of 5.86 and 5.84, respectively). However, tourism development received the last ranking since only few respondents perceived that RES transition would contribute to the development of tourism in the surrounding areas.

Table 5. The rankings of the non-parametric Friedman test regarding citizens' opinion on the impacts of replacing lignite plants with renewable energy sources.

\begin{tabular}{cc}
\hline Impacts & Mean Rank \\
\hline Improved life quality & 5.93 \\
Regional economic development & 4.48 \\
Creation of new jobs & 4.34 \\
Tourism development & 3.83 \\
Landscape enhancement & 5.29 \\
Local fauna protection & 5.84 \\
Local flora protection & 5.86 \\
Agriculture development & 4.71 \\
Livestock farming development & 4.71 \\
\hline$n=420$ Chi-Square $=388.294 \mathrm{df}=8 p<0.001$.
\end{tabular}


To gain further insights into participants' views on impacts of lignite replacement with RES, factor analysis was deemed appropriate. Before proceeding, the eligibility of the data had to be tested. Hence, the Cronbach's alpha value was 0.947, the Keiser-Meyer Olkin index value was 0.852 and Bartlett's test of sphericity gave $\chi^{2}=7782.354, d f=36$ and $p<0.001$, indicating our data were suitable for factor analysis. After performing Varimax rotation, two factors emerged for the multivariate "Impacts of replacing lignite plants with renewable energy sources on the surrounding areas" (Table 6). Specifically, the first factor (PC1) includes the variables "Local flora protection", "Local fauna protection", "Agriculture development", "Livestock farming development ", "Landscape enhancement" and "Tourism development". The second factor (PC2) contains the variables "Regional economic development", "Creation of new jobs" and "Improved life quality".

Table 6. Rotated component matrix for citizens' views on the regional impacts due to replacing lignite plants with RES.

\begin{tabular}{clc}
\hline \multirow{2}{*}{ Variables } & \multicolumn{2}{c}{ Rotated Matrix } \\
\cline { 2 - 3 } & PC 1 & PC 2 \\
\hline Local flora protection & 0.923 & 0.249 \\
Local fauna protection & 0.920 & 0.260 \\
Agriculture development & 0.907 & 0.267 \\
Livestock farming development & 0.907 & 0.267 \\
Landscape enhancement & 0.900 & 0.274 \\
Tourism development & 0.774 & 0.248 \\
Regional economic development & 0.261 & 0.934 \\
Creation of new jobs & 0.180 & 0.925 \\
Improved life quality & 0.541 & 0.662 \\
\hline
\end{tabular}

Then, respondents assessed different energy sources based on which they wished to be developed in Greece. At this point, responses were ranked with the non-parametric Friedman test. As tabulated in Table 7, solar energy was ranked first with a mean rank of 7.66, followed by wind energy and hydropower with mean ranks of 7.30 and 6.95, respectively. Finally, coal combustion was the least preferred energy option (mean rank 2.67).

Table 7. The application of the Friedman test for ranking respondents' evaluation of different energy production technologies.

\begin{tabular}{cc}
\hline Energy Production Technologies & Mean Rank \\
\hline Lignite combustion & 2.86 \\
Coal combustion & 2.67 \\
Oil combustion & 3.03 \\
Natural gas combustion & 5.45 \\
Hydropower & 6.95 \\
Wind energy & 7.30 \\
Solar energy & 7.66 \\
Nuclear fuels & 2.91 \\
Biofuels & 6.16 \\
\hline$n=420$ Chi-Square $=2341.566 d f=8 p<0.001$.
\end{tabular}

Before performing factor analysis, the suitability of the data had to be verified and thus the Bartlett test of sphericity, Cronbach Alpha and the Keiser-Meyer-Olkin measure were applied. Thus, the Cronbach's Alpha scored 0.773, the KMO index was 0.775 and Bartlett's test of sphericity gave $\chi^{2}=$ $1981,398, d f=36, p<0.001$. After performing the varimax rotation, two factors were extracted for the value variables. As it appears in Table 8, the variables "Solar energy", "Wind energy", "Hydropower" and "Biofuels" fell under the first factor (PC1), whereas the variables "Coal combustion", "Lignite 
combustion", "Oil combustion", "Nuclear fuels" and "Natural gas combustion" fell under the second factor (PC2).

Table 8. Rotated component matrix for respondents' evaluation of energy production technologies.

\begin{tabular}{ccc}
\hline \multirow{2}{*}{ Variables } & \multicolumn{2}{c}{ Rotated Matrix } \\
\cline { 2 - 3 } & PC 1 & PC 2 \\
\hline Solar energy & 0.910 & 0.025 \\
Wind energy & 0.910 & -0.001 \\
Hydropower & 0.874 & 0.135 \\
Biofuels & 0.612 & 0.004 \\
Coal combustion & -0.038 & 0.900 \\
Lignite combustion & -0.024 & 0.875 \\
Oil combustion & 0.092 & 0.810 \\
Nuclear fuels & 0.076 & 0.568 \\
Natural gas combustion & 0.460 & 0.517 \\
\hline
\end{tabular}

The surveyed citizens were then asked whether they were interested in investing in a photovoltaic system as house owners. Remarkably, the clear majority of participants (by $91.9 \%$ ) showed interest in a future investment, while only $8.1 \%$ were not interested (Table 9).

Table 9. Frequency and percentages regarding citizens' interest in investing in photovoltaic systems in the future.

\begin{tabular}{ccc}
\hline & Frequency & Percentage (\%) \\
\hline Yes & 386 & 91.9 \\
No & 34 & 8.1 \\
Total & 420 & 100.0 \\
\hline
\end{tabular}

Respondents also evaluated various reasons for installing photovoltaic systems. To investigate if there were any statistical differences among the reasons, the non-parametric Friedman test was applied. As Table 10 shows, the citizens under study considered the improved air quality as the most important reason to install photovoltaic systems with a mean rank of 9.31, whereas they assigned the lowest ranking to the minimum amount of work that is often required for the system installation.

Table 10. The application of the Friedman test for ranking reasons for installing photovoltaic systems.

\begin{tabular}{cc}
\hline Reasons for Installing Photovoltaic Systems & Mean Rank \\
\hline Subsidies for the purchase of RE system & 6.47 \\
Subsidies for the maintenance of the system & 5.98 \\
Fixed and guaranteed income & 6.82 \\
Minimum amount of work & 4.75 \\
Lower-risk investment for savings & 6.05 \\
Higher profitability compared to other investments & 6.18 \\
Tax exemptions due to installation cost of RE & 6.97 \\
Tax exemptions due to maintenance cost of RE & 6.75 \\
New job positions-unemployment reduction & 7.37 \\
Enhanced social prestige-entrepreneurial activity & 5.93 \\
Reduction in pollution & 9.27 \\
Improved air quality & 9.31 \\
Increased energy independence of our country & 9.14 \\
\hline \multicolumn{2}{c}{$n=420$ Chi-Square $=1038.803 \mathrm{df}=12 p<0.001$} \\
\hline
\end{tabular}

Before conducting factor analysis to extract factors, the adequacy of the data had to be tested. To this end, the Cronbach test of reliability, the KMO index and the Bartlett test were employed. Thus, 
the Cronbach's alpha value was as high as 0.885 , the Keiser-Meyer-Olkin index value was 0.835 and the Bartlett test of sphericity value was 3222.800, with degrees of freedom 78 and with $p<0.001$, confirming our data's suitability. Next, principal component analysis with varimax rotation was performed and three factors were loaded for the (Table 11). The variables "Higher profitability compared to other investments", "Enhanced social prestige-entrepreneurial activity", "Lower-risk investment for savings", "New job positions-unemployment reduction", "Tax exemptions due to installation cost of $\mathrm{RE}$ " and "Tax exemptions due to maintenance cost of RE" fell under the first factor (PC1). The second factor (PC2) contained the variables "Improved air quality", "Reduction in pollution" and "Increased energy independence of our country". Finally, the variables "Subsidies for the maintenance of the system", "Minimum amount of work", "Subsidies for the purchase of RE system" and "Fixed and guaranteed income" loaded on the third factor (PC3).

Table 11. Reasons for installing photovoltaic systems.

\begin{tabular}{cccc}
\hline Variable & \multicolumn{3}{c}{ Rotated Matrix } \\
\cline { 2 - 4 } & PC 1 & PC 2 & PC 3 \\
\hline Higher profitability compared to other investments & 0.800 & 0.084 & 0.250 \\
Enhanced social prestige-entrepreneurial activity & 0.775 & 0.216 & 0.010 \\
Lower-risk investment for savings & 0.708 & 0.186 & 0.284 \\
New job positions-unemployment reduction & 0.637 & 0.418 & 0.171 \\
Tax exemptions due to installation cost of RE & 0.595 & 0.124 & 0.495 \\
Tax exemptions due to maintenance cost of RE & 0.566 & 0.102 & 0.509 \\
Improved air quality & 0.171 & 0.921 & 0.112 \\
Reduction in pollution & 0.194 & 0.902 & 0.127 \\
Increased energy independence of our country & 0.213 & 0.881 & 0.121 \\
Subsidies for the maintenance of the system & 0.104 & 0.112 & 0.813 \\
Minimum amount of work & 0.081 & -0.016 & 0.692 \\
Subsidies for the purchase of RE system & 0.327 & 0.189 & 0.665 \\
Fixed and guaranteed income & 0.262 & 0.181 & 0.650 \\
\hline
\end{tabular}

\section{Discussion}

Exceeding our expectation, participants expressed a favorable stance to environmentally benign energy sources and showed an intention to transition to a "clean" energy system, while they disagreed with the construction of new lignite plants in areas of Greece where lignite reserves are located. In disagreeing with the establishment of new lignite plants, it is possible that participants acknowledged the negative effects and approaching depletion of fossil fuels $[15,35]$.

What is more, the respondents attached greater importance to the environmental protection rather than economic prospects of renewable energy investments. Hence, it is possible that citizens, who were concerned about the environment and its problems, would adopt renewable energy in an effort to contribute to the solution of environmental problems. The interpretation that increased environmental awareness motivates individuals to support renewable energy resonates with the research of Viklund [6], Altuntaş and Turan [19] and Ektör-Akyazi et al. [51], who have also observed that individuals with environmental awareness tend to adopt environmentally friendly behavior including the decision-making on energy choices. From this perspective, it can be seen that raising environmental awareness among social groups can play a critical role in tackling environmental issues. It is also important to note that apart from our respondents in the Thessaloniki conurbation, other studies have also indicated that citizens in other regions of Greece were supportive towards renewable energy deployment [8]. Hence, it appears that citizens throughout Greece are becoming mindful about energy and express positive attitudes, giving a sense of hope and optimism about the future of renewable energy in Greece.

Another point that is worthwhile to discuss is that respondents appeared to value the ability of renewable energy to achieve energy independence. Based on this, it is also possible that they 
acknowledged the potential of renewables to protect households from energy poverty. At the same time, of all renewable types citizens were more supportive towards solar energy and this support could be attributed simply to the fact that as a Mediterranean country Greece has abundant sunlight throughout the year [69] and hence it only made sense to respondents that solar energy can make the greatest contribution to increasing the national energy independence while decreasing the dependence on imported fuels.

On the other side, there are challenges to be faced for an increased installation of domestic photovoltaic systems. Most notably, the lack of incentives and accurate public information inhibit citizen investments. Regarding incentives, these should focus more on the rationalization of the guaranteed kilowatt rate and on the enhancement of the subsidies provided for green innovations, since it has been shown that the provision of incentives to household owners could result in increased building energy efficiency but also in substantial behavior change [70]. In turn, increased investment in domestic photovoltaics can effectively tackle energy poverty which is threatening many Greek households due to the economic crisis.

Much to our surprise, most respondents considered that the Greek state has not invested in renewable energy. However, Greece has already met the set targets regarding the increase in the share of renewable energy in total energy production [35]. To clarify why participants held this wrong view, a future study should investigate the citizens' level of knowledge on renewable energy implementation as well as explore the information sources from which they obtained such information.

Remarkably, the overwhelming majority of citizens (91.9\%) were willing to make investments in photovoltaic systems in the future confirming previous research results $[35,55]$, which also indicated that citizens were expressing a pronounced willingness to invest in renewable energy systems or pay more for energy generated from renewables.

Although the present study has identified positive attitudes to renewable energy, greater levels are needed to achieve the desired transition to a low-carbon society. To that end, information campaigns should be frequently held to inform citizens of all ages about the benefits of renewable energy and other environmental topics. Simultaneously, it is of paramount importance to shape positive attitudes in young individuals and this could be managed through environmental education programs targeted to school students. However, at present the study program in Greek schools is rather strict [71] preventing educators from organizing frequent environmental programs. Consequently, there are limited opportunities to provide information and raise awareness about the environment among adolescents who are the future citizens [72]. In this regard, it is considered essential to integrate courses focusing on environmental and energy topics in the academic programs of primary and secondary education. That is because it has been reported that environmental educational programs can shape pro-environmental behavior [13,73]. In turn, the adoption of environmentally conscious behavior that is shaped through educational programs aiming to create "green" consciousness in students, contributes significantly to energy saving, and a reduction in greenhouse gas emissions $[55,74]$.

\section{Conclusions}

The present study investigated the investment willingness and the views on energy-related topics of citizens living in the Thessaloniki conurbation in order to examine whether it is possible to address energy poverty through investments in renewable energy. In view of the study's findings, it can be inferred that most participants were willing to make investments in renewables in the future and expressed positive attitudes to renewable energy. The findings highlight that citizens' positive attitudes to RES investment are particularly important, mainly because citizen investment could protect households, especially lower-income ones, from energy poverty and price fluctuations in the energy market. Moreover, higher citizen investment in renewable energy can contribute to the desired transition to a low-carbon energy system and the protection of the climate.

It is crucial to develop policies and incentives which are tailored for citizens with low incomes as such measures could not only speed up the energy transition to an environmentally harmless system, 
but also protect households from energy poverty. In other words, to induce citizens to invest, it is necessary to develop policies and incentives which create a favorable investment environment not only for household owners seeking to enhance their income, but also for low-income households, since the latter run a greater danger of encountering energy poverty. The major themes of these policies should be the formation of a favorable environment for RES installation enabling lower-income households to have their own energy production and consumption through low-interest lending including lower interest rates. These measures could achieve a significant reduction in the electricity bill costs for heating/cooling/domestic warm water. Moreover, lower-income households could be offered specific subsidies and tax breaks when purchasing or maintaining a renewable energy system, whereas citizens who do not own a house or a plot of land should also be provided with the opportunity to invest in renewables by renting roofs or plots of land at a low price to install photovoltaic systems.

As already mentioned, the citizens under scrutiny appeared to be highly aware of the environment and its issues. This conclusion rests upon two study findings. Specifically, in evaluating impacts resulting from the replacement of lignite plants with renewable energy sources, respondents attached greater importance to impacts that had to do with the protection of the environment, such as improved air quality and local flora/fauna protection. In addition, most participants would invest in photovoltaic systems for environmental (such as pollution reduction, air quality) rather than financial reasons (such as subsidies). Hence, the present study findings highlight that individuals with pro-environmental attitudes are more likely to make investments and in view of this inference it is of the utmost importance that strategies are developed to raise environmental awareness among different social groups.

In addition, citizens had a good grasp of different energy sources and were able to distinguish between renewable and non-renewable types. This was indicated by the results of factor analysis according to which explicitly renewable energy types fell under the first factor and conventional types under the second. Therefore, these factor loadings made apparent that citizens could identify between sustainable and unsustainable energy types.

Finally, in view of the findings certain additional recommendations could be made. In specific, similar studies should be carried out more frequently and in a systematic manner to analyze public attitudes to renewable energy and investments. That is because frequent measurements could prevent possible public disappointments or low participation in renewable energy investments and at the same time help policymakers to make timely improvements and modifications in the existing policies and incentives. In other words, the overall aims of such analyses should be to detect weaknesses and problems which affect citizens' willingness to invest in renewable energy. Moreover, further information about individuals' desires, expectations and needs in relation to RES investment should be acquired since this knowledge can enable policymakers to design policies which correspond to the current circumstances and induce citizens to make investments. From this perspective, study findings, such as the ones presented in this paper, may form the basis for a set of preparatory actions and policymaking which aim at planning properly the development and installation of renewable energy, as well as addressing energy poverty.

Author Contributions: M.P., N.K. and S.L. reviewed the relevant literature. S.-D.P. collected the data and performed statistical analysis. E.K. prepared the methodology. S.-D.P. and E.K. wrote the original draft and then E.K. and G.T. reviewed and edited the manuscript. G.T. supervised and coordinated the work.

Funding: This research received no external funding.

Conflicts of Interest: The authors declare no conflict of interest.

\section{References}

1. Kaldellis, J.K.; Kapsali, M.; Katsanou, E. Renewable energy applications in Greece-What is the public attitude? Energy Policy 2012, 42, 37-48. [CrossRef]

2. West, J.; Bailey, I.; Winter, M. Renewable energy policy and public perceptions of renewable energy: A cultural theory approach. Energy Policy 2010, 38, 5739-5748. [CrossRef] 
3. Michalena, E.; Hills, J.M. Renewable energy issues and implementation of European energy policy: The missing generation? Energy Policy 2012, 45, 201-216. [CrossRef]

4. Kontogianni, A.; Tourkolias, C.; Skourtos, M. Renewables portfolio, individual preferences and social values towards RES technologies. Energy Policy 2013, 55, 467-476. [CrossRef]

5. Fischer, A.; Peters, V.; Vávra, J.; Neebe, M.; Megyesi, B. Energy use, climate change and folk psychology: Does sustainability have a chance? Results from a qualitative study in five European countries. Glob. Environ. Chang. 2011, 21, 1025-1034. [CrossRef]

6. Viklund, M. Energy policy options-From the perspective of public attitudes and risk perceptions. Energy Policy 2004, 32, 1159-1171. [CrossRef]

7. Owens, S.; Driffill, L. How to change attitudes and behaviours in the context of energy. Energy Policy 2008, 36, 4412-4418. [CrossRef]

8. Kaldellis, J.K. Social attitude towards wind energy applications in Greece. Energy Policy 2005, 33, 595-602. [CrossRef]

9. Hondo, H.; Baba, K. Socio-psychological impacts of the introduction of energy technologies: Change in environmental behavior of households with photovoltaic systems. Appl. Energy 2010, 87, 229-235. [CrossRef]

10. Tomprou, Z. Energy Poverty in Europe and Greece during Economic Crisis, Case Study: Attica Regiontle; National Technical University: Athens, Greece, 2017.

11. Aligizaki, A. Internal Energy Market as an "Antidote" for Energy Insecurity in Europe; University of Piraeus, Department of International and European Studies: Piraeus, Greece, 2015.

12. Ntona, E.; Arabatzis, G.; Kyriakopoulos, G.L. Energy saving: Views and attitudes of students in secondary education. Renew. Sustain. Energy Rev. 2015, 46, 1-15. [CrossRef]

13. Lee, L.-S.; Lin, K.-Y.; Guu, Y.-H.; Chang, L.-T.; Lai, C.-C. The effect of hands-on 'energy-saving house' learning activities on elementary school students' knowledge, attitudes, and behavior regarding energy saving and carbon-emissions reduction. Environ. Educ. Res. 2013, 19, 620-638. [CrossRef]

14. Bergmann, A.; Hanley, N.; Wright, R. Valuing the attributes of renewable energy investments. Energy Policy 2006, 34, 1004-1014. [CrossRef]

15. Tampakis, S.; Arabatzis, G.; Tsantopoulos, G.; Rerras, I. Citizens' views on electricity use, savings and production from renewable energy sources: A case study from a Greek island. Renew. Sustain. Energy Rev. 2017, 79, 39-49. [CrossRef]

16. Kalogirou, S. Thermal performance, economic and environmental life cycle analysis of thermosiphon solar water heaters. Sol. Energy 2009, 83, 39-48. [CrossRef]

17. Diakoulaki, D.; Zervos, A.; Sarafidis, J.; Mirasgedis, S. Cost benefit analysis for solar water heating systems. Energy Convers. Manag. 2001, 42, 1727-1739. [CrossRef]

18. Dimitropoulos, A.; Kontoleon, A. Assessing the determinants of local acceptability of wind-farm investment: A choice experiment in the Greek Aegean Islands. Energy Policy 2009, 37, 1842-1854. [CrossRef]

19. Çakirlar Altuntaş, E.; Turan, S.L. Awareness of secondary school students about renewable energy sources. Renew. Energy 2018, 116, 741-748. [CrossRef]

20. Rustemli, S.; Dincer, F.; Unal, E.; Karaaslan, M.; Sabah, C. The analysis on sun tracking and cooling systems for photovoltaic panels. Renew. Sustain. Energy Rev. 2013, 22, 598-603. [CrossRef]

21. European Commission. Communication from the Commission, Europe 2020: A Strategy for Smart, Sustainable and Inclusive Growth. Available online: http://ec.europa.eu/europe2020/index_en.htm (accessed on 10 March 2019).

22. European Commission. Energy Roadmap. Available online: https://ec.europa.eu/energy/sites/ener/files/ documents/2012_energy_roadmap_2050_en_0.pdf (accessed on 10 March 2019).

23. Neagu, O.; Teodoru, M. The Relationship between Economic Complexity, Energy Consumption Structure and Greenhouse Gas Emission: Heterogeneous Panel Evidence from the EU Countries. Sustainability 2019, 11, 497. [CrossRef]

24. Lacal Arantegui, R.; Jäger-Waldau, A. Photovoltaics and wind status in the European Union after the Paris Agreement. Renew. Sustain. Energy Rev. 2018, 81, 2460-2471. [CrossRef]

25. Scarlat, N.; Dallemand, J.-F.; Monforti-Ferrario, F.; Banja, M.; Motola, V. Renewable energy policy framework and bioenergy contribution in the European Union-An overview from National Renewable Energy Action Plans and Progress Reports. Renew. Sustain. Energy Rev. 2015, 51, 969-985. [CrossRef] 
26. Knight, D.M.; Bell, S. Pandora's box: Photovoltaic energy and economic crisis in Greece. J. Renew. Sustain. Energy 2013, 5, 033110. [CrossRef]

27. Ministry of Environment and Energy. Energy Policy-International Relations. Available online: http: //www.ypeka.gr/Default.aspx?tabid=275\&language=el-RG (accessed on 9 March 2019).

28. Ministry of Environment and Energy Energy. Available online: http://www.ypeka.gr/Default.aspx?tabid= 225\&language $=\mathrm{el}-\mathrm{RG}$ (accessed on 9 March 2019).

29. Katsaprakakis, D.A.; Christakis, D.G. The exploitation of electricity production projects from Renewable Energy Sources for the social and economic development of remote communities. The case of Greece: An example to avoid. Renew. Sustain. Energy Rev. 2016, 54, 341-349. [CrossRef]

30. Koutalakis, C. Chapter 9 Environmental policy in Greece reloaded: Plurality, participation and the Sirens of neo-centralism. In Sustainable Politics and the Crisis of the Peripheries: Ireland and Greece; Leonard, L., Botetzagias, I., Eds.; Emerald Group Publishing Limited: Bingley, UK, 2011; pp. 181-200.

31. Argenti, N.; Knight, D.M. Sun, wind, and the rebirth of extractive economies: Renewable energy investment and metanarratives of crisis in Greece. J. R. Anthropol. Inst. 2015, 21, 781-802. [CrossRef]

32. Markantonatou, M. Diagnosis, Treatment, and Effects of the Crisis in Greece: A "Special Case" or a "Test Case"? Max Planck Institute for the Study of Societies: Cologne, Germany, 2013.

33. Lekakis, J.N.; Kousis, M. Economic Crisis, Troika and the Environment in Greece. South Eur. Soc. Politics 2013, 18, 305-331. [CrossRef]

34. Faiers, A.; Neame, C. Consumer attitudes towards domestic solar power systems. Energy Policy 2006, 34, 1797-1806. [CrossRef]

35. Tsantopoulos, G.; Arabatzis, G.; Tampakis, S. Public attitudes towards photovoltaic developments: Case study from Greece. Energy Policy 2014, 71, 94-106. [CrossRef]

36. Ministry of Environment and Energy. Energy-Power Generation. Available online: http://www.ypeka.gr/ Default.aspx?tabid=277\&language=el-GR\# (accessed on 9 March 2019).

37. Griffiths, S. Strategic considerations for deployment of solar photovoltaics in the Middle East and North Africa. Energy Strateg. Rev. 2013, 2, 125-131. [CrossRef]

38. Fthenakis, V. Sustainability of photovoltaics: The case for thin-film solar cells. Renew. Sustain. Energy Rev. 2009, 13, 2746-2750. [CrossRef]

39. Ministry of Environment and Energy. Renewable Energy Sources. Available online: http://www.ypeka.gr/ Default.aspx?tabid=285\&language=el-GR (accessed on 9 March 2019).

40. Kaldellis, J.K.; Kapsali, M.; Kaldelli, E.; Katsanou, E. Comparing recent views of public attitude on wind energy, photovoltaic and small hydro applications. Renew. Energy 2013, 52, 197-208. [CrossRef]

41. Korjonen-Kuusipuro, K.; Hujala, M.; Pätäri, S.; Bergman, J.-P.; Olkkonen, L. The emergence and diffusion of grassroots energy innovations: Building an interdisciplinary approach. J. Clean. Prod. 2017, 140, 1156-1164. [CrossRef]

42. Keirstead, J. Behavioural responses to photovoltaic systems in the UK domestic sector. Energy Policy 2007, 35, 4128-4141. [CrossRef]

43. Ozden, T.; Akinoglu, B.G.; Turan, R. Long term outdoor performances of three different on-grid PV arrays in central Anatolia-An extended analysis. Renew. Energy 2017, 101, 182-195. [CrossRef]

44. Klick, H.; Smith, E.R.A.N. Public understanding of and support for wind power in the United States. Renew. Energy 2010. [CrossRef]

45. Graham, J.B.; Stephenson, J.R.; Smith, I.J. Public perceptions of wind energy developments: Case studies from New Zealand. Energy Policy 2009, 37, 3348-3357. [CrossRef]

46. Ek, K. Public and private attitudes towards "green" electricity: The case of Swedish wind power. Energy Policy 2005, 33, 1677-1689. [CrossRef]

47. Swofford, J.; Slattery, M. Public attitudes of wind energy in Texas: Local communities in close proximity to wind farms and their effect on decision-making. Energy Policy 2010, 38, 2508-2519. [CrossRef]

48. Tian, W.; Wang, Y.; Ren, J.; Zhu, L. Effect of urban climate on building integrated photovoltaics performance. Energy Convers. Manag. 2007, 48, 1-8. [CrossRef]

49. Devine-Wright, P. Beyond NIMBYism: Towards an integrated framework for understanding public perceptions of wind energy. Wind Energy 2005, 8, 125-139. [CrossRef] 
50. Frederiks, E.R.; Stenner, K.; Hobman, E.V. Household energy use: Applying behavioural economics to understand consumer decision-making and behaviour. Renew. Sustain. Energy Rev. 2015, 41, 1385-1394. [CrossRef]

51. Ertör-Akyazı, P.; Adaman, F.; Özkaynak, B.; Zenginobuz, Ü. Citizens' preferences on nuclear and renewable energy sources: Evidence from Turkey. Energy Policy 2012, 47, 309-320. [CrossRef]

52. Warren, C.R.; McFadyen, M. Does community ownership affect public attitudes to wind energy? A case study from south-west Scotland. Land Use Policy 2010, 27, 204-213. [CrossRef]

53. Liu, W.; Wang, C.; Mol, A.P.J. Rural public acceptance of renewable energy deployment: The case of Shandong in China. Appl. Energy 2013, 102, 1187-1196. [CrossRef]

54. Zografakis, N.; Sifaki, E.; Pagalou, M.; Nikitaki, G.; Psarakis, V.; Tsagarakis, K.P. Assessment of public acceptance and willingness to pay for renewable energy sources in Crete. Renew. Sustain. Energy Rev. 2010, 14, 1088-1095. [CrossRef]

55. Tsagarakis, K.P.; Bounialetou, F.; Gillas, K.; Profylienou, M.; Pollaki, A.; Zografakis, N. Tourists' attitudes for selecting accommodation with investments in renewable energy and energy saving systems. Renew. Sustain. Energy Rev. 2011, 15, 1335-1342. [CrossRef]

56. Braito, M.; Flint, C.; Muhar, A.; Penker, M.; Vogel, S. Individual and collective socio-psychological patterns of photovoltaic investment under diverging policy regimes of Austria and Italy. Energy Policy 2017, 109, 141-153. [CrossRef]

57. Zhai, P.; Williams, E.D. Analyzing consumer acceptance of photovoltaics (PV) using fuzzy logic model. Renew. Energy 2012, 41, 350-357. [CrossRef]

58. Firestone, J.; Bidwell, D.; Gardner, M.; Knapp, L. Wind in the sails or choppy seas?: People-place relations, aesthetics and public support for the United States' first offshore wind project. Energy Res. Soc. Sci. 2018, 40, 232-243. [CrossRef]

59. Hui, I.; Cain, B.E.; Dabiri, J.O. Public receptiveness of vertical axis wind turbines. Energy Policy 2018, 112, 258-271. [CrossRef]

60. Scherhaufer, P.; Höltinger, S.; Salak, B.; Schauppenlehner, T.; Schmidt, J. Patterns of acceptance and non-acceptance within energy landscapes: A case study on wind energy expansion in Austria. Energy Policy 2017. [CrossRef]

61. Gadenne, D.; Sharma, B.; Kerr, D.; Smith, T. The influence of consumers' environmental beliefs and attitudes on energy saving behaviours. Energy Policy 2011, 39, 7684-7694. [CrossRef]

62. Norton, B.; Eames, P.C.; Mallick, T.K.; Huang, M.J.; McCormack, S.J.; Mondol, J.D.; Yohanis, Y.G. Enhancing the performance of building integrated photovoltaics. Sol. Energy 2011, 85, 1629-1664. [CrossRef]

63. Wilcox, J.B.; Rossi, P.H.; Wright, J.D.; Anderson, A.B. Handbook of Survey Research. J. Mark. Res. 1985, 22, 100. [CrossRef]

64. Freund, R.J.; Wilson, W.J.; Mohr, D.L. Data and Statistics. In Statistical Methods; Academic Press: Cambridge, UK, 2012.

65. Ho, R. Handbook of Univariate and Multivariate Data Analysis with IBM SPSS; Chapman \& Hall/CRC: Boca Raton, FL, USA, 2006; ISBN 9781439890226.

66. Schuenemeyer, J.H.; Murtagh, F.; Heck, A. Multivariate Data Analysis. Technometrics 2006, 49, $103-104$. [CrossRef]

67. Jolliffe, I.T. Principal Component Analysis, 2nd ed.; Springer: New York, NY, USA, 2002; ISBN 0-387-95442-2.

68. Maxwell, A.E.; Harman, H.H. Modern Factor Analysis. J. R. Stat. Soc. Ser. A 1968, 131, 615-616. [CrossRef]

69. Ntanos, S.; Kyriakopoulos, G.; Chalikias, M.; Arabatzis, G.; Skordoulis, M.; Galatsidas, S.; Drosos, D. A social assessment of the usage of Renewable Energy Sources and its contribution to life quality: The case of an Attica Urban area in Greece. Sustainability 2018, 10, 1414. [CrossRef]

70. Kowalska-Pyzalska, A. What makes consumers adopt to innovative energy services in the energy market? A review of incentives and barriers. Renew. Sustain. Energy Rev. 2018, 82, 3570-3581. [CrossRef]

71. Liarakou, G.; Gavrilakis, C.; Flouri, E. Secondary school teachers' knowledge and attitudes towards renewable energy sources. J. Sci. Educ. Technol. 2009, 18, 120-129. [CrossRef]

72. Manolas, E.I. Environmental education programs in greek secondary schools: Practices, Problems and promises. In Environmental Education in Context: An International Perspective on the Development of Environmental Education; Taylor, N., Littledyke, M., Eames, C., Coll, R., Eds.; SENSE Publishers: Roterdam, The Netherlands; Boston, MA, USA; Taipei, Taiwan, 2009; pp. 83-98. 
73. Liefländer, A.K.; Bogner, F.X.; Kibbe, A.; Kaiser, F.G. Evaluating Environmental Knowledge Dimension Convergence to Assess Educational Programme Effectiveness. Int. J. Sci. Educ. 2015, 37, 684-702. [CrossRef]

74. Mirza, U.K.; Harijan, K.; Majeed, T. Status and need of energy education: The case of Pakistan. In Energy, Environment and Sustainable Development; Uqaili, M.A., Harijan, K., Eds.; Springer Werlag: Wien, Austria, 2012; pp. 39-49. ISBN 9783709101094.

(c)

(C) 2019 by the authors. Licensee MDPI, Basel, Switzerland. This article is an open access article distributed under the terms and conditions of the Creative Commons Attribution (CC BY) license (http://creativecommons.org/licenses/by/4.0/). 